\title{
Community-acquired viral pneumonia in human immunodeficiency virus infected patients
}

\author{
Catia Cillóniz, Shinobu Yamamoto, Ernesto Rangel ${ }^{1}$, Antoni Torres
}

Department of Pneumology, Clinical Thoracic Institut, Hospital Clinic of Barcelona, University of Barcelona, August Pi i Sunyer Biomedical Research Institute (IDIBAPS), Center for Biomedical Research Network for Respiratory Diseases (CIBERES), Spain, ${ }^{1}$ Faculty of Medicine, Autonomous University of Nayarit, Mexico

\begin{abstract}
Respiratory viruses (RV) have become an important cause of community-acquired pneumonia in immunocompromised patients with the highest rates of morbidity and mortality. The advances in molecular diagnostic methods have increased our understanding of the role of viruses in pneumonia. However, little is known about their impact on patients with human immunodeficiency virus (HIV) infection. In this review, we focus on the most prevalent RV that has been implicated in viral respiratory infections, particularly in pneumonia in HIV infected patients. We discuss the epidemiologic characteristics and clinical presentations of these viral infections and the most appropriate diagnostic approaches and therapies if available.
\end{abstract}

Key words: Human immunodeficiency virus, respiratory virus, viral pneumonia

\section{INTRODUCTION}

Community-acquired pneumonia (CAP) is a serious health problem associated with high morbidity and mortality in all age groups worldwide. ${ }^{[1]} \mathrm{CAP}$ is the sixth cause of death across the world and is a major burden on healthcare resources. ${ }^{[1]}$ Respiratory viruses (RV), in particular influenza viruses $\mathrm{A}$ and $\mathrm{B}$, rhinoviruses, parainfluenza viruses 1,2 , and 3 , and coronaviruses, are considered as the etiological agents in almost one-third of the CAP cases. It is estimated that 100 million cases of viral pneumonia occur every year

\section{Address for correspondence:}

Dr. Antoni Torres, Department of Respiratory Disease, Institut Clínic del Tórax, Hospital Clinic i Provincial de Barcelona, Institut d'Investigacions Biomèdiques August Pi i Sunyer, Ciber de Enfermedades Respiratorias, Calle Villarroel 170 08036, Barcelona, Spain.

E-mail: atorresi@clinic.ub.es

\begin{tabular}{|c|l|}
\hline Access this article online & \\
\hline Quick Response Code: & \\
\hline & Website: \\
& www.caijournal.com \\
& \\
\hline
\end{tabular}

globally. ${ }^{[2]}$ The development of new diagnostic tools has aided better detection of viral pneumonia in the recent years, and viral etiologies have been reported in approximately $23 \%$ of pneumonia among inmunocompromised patients. ${ }^{[3,4]}$ However, there are only few studies on RV in patients with human immunodeficiency virus (HIV) infection summarized on Table 1.

Human immunodeficiency virus-infected patients present deficiencies in humoral and cell-mediated immunity that can potentially alter the course and severity of common infections ${ }^{[9]}$ Despite antiretroviral therapy (ART), some HIV patients, especially those with impaired antigen specific responses, may remain at risk for morbidity associated with respiratory viral infections. ${ }^{[9]}$ Additional risk factors for the infections in HIV patients are active smoking and chronic lung comorbidities. The objective of this article is to review the main RV that cause CAP in HIV patients and to discuss their epidemiologies, clinical presentations, diagnosis, and treatments.

\section{EPIDEMIOLOGY}

Approximately, 100 million cases of viral pneumonia are reported in adults annually. ${ }^{[2]}$ Recent studies of CAP in adult population demonstrated that approximately $1-30 \%$ of the cases are caused by RV; influenza viruses 
Cillóniz, et al.: Viral pneumonia in HIV infected patients

\begin{tabular}{|c|c|c|c|c|}
\hline Study & $\begin{array}{l}\text { Country/year of } \\
\text { publication }\end{array}$ & Study period & Population & Percentages of respiratory virus (\%) \\
\hline Garbino et al..$^{[5]}$ & Swiss/2008 & $\begin{array}{l}\text { November } 2003 \text { and } \\
\text { November } 2006\end{array}$ & $\begin{array}{l}\text { HIV-infected patients with } \\
\text { respiratory infections } \\
59 \text { samples of BAL of } 55 \\
\text { HIV patients }\end{array}$ & $\begin{array}{l}\text { Respiratory virus } 11 \text { (18.6) } \\
\text { Coronavirus OC43 (27.3) } \\
\text { Influenza A (18.2) } \\
\text { PIV 2, PIV 3, PIV } 4 \text { (9) } \\
\text { Bocavirus (9) } \\
\text { Human rhinovirus A (9) } \\
\text { HMPV (9) }\end{array}$ \\
\hline Perelló et al. ${ }^{[6]}$ & Spain/2008 & $\begin{array}{l}3 \text { years of study } \\
67 \text { cases }\end{array}$ & $\begin{array}{l}\text { HIV-infected patients with } \\
\text { pneumonia } \\
28,000 \text { patients with ALRI }\end{array}$ & $\begin{array}{l}\text { Respiratory viruses (20.8) } \\
\text { Rhinovirus } 5 \\
\text { Adenovirus } 2 \\
\text { Influenza A and B virus }\end{array}$ \\
\hline Feng et al..$^{[7]}$ & China/2014 & $\begin{array}{l}\text { January } \\
\text { 2009-September } 2013\end{array}$ & $\begin{array}{l}\text { ALRIs inmmunocompetent } \\
\text { patients }\end{array}$ & $\begin{array}{l}\text { Respiratory viruses } 10,387 \text { (36.6), included } \\
7.2 \% \text { of co-infection } \\
\text { Respiratory syncitial virus (9.9) } \\
\text { Influenza virus (6.6) } \\
\text { Para influenza viruses (4.8) } \\
\text { Adenovirus (3.4) } \\
\text { Bocavirus (1.9) } \\
\text { HMPV (1.5) } \\
\text { Coronavirus (1.4) }\end{array}$ \\
\hline Cilloniz et al..$^{[8]}$ & Spain/2014 & $\begin{array}{l}\text { January } 2007 \text { and } \\
\text { July } 2012\end{array}$ & $\begin{array}{l}\text { HIV-infected patients with } \\
\text { pneumonia } \\
331 \text { cases }\end{array}$ & $\begin{array}{l}\text { Respiratory viruses } 18 \text { (5.4) } \\
\text { Influenza A and B virus } \\
\text { Adenovirus } \\
\text { Rhinovirus }\end{array}$ \\
\hline
\end{tabular}

Data: $N$ (\%). CAP: Community-acquired pneumonia; BAL: Bronchoalveolar lavage; ALRI: Acute lower respiratory infection; PIV: Parainfluenza virus; HMPV: Human metapneumovirus; HIV: Human immunodeficiency virus

$\mathrm{A}$ and $\mathrm{B}$, rhinoviruses, parainfluenza viruses 1,2 , and 3 , and coronaviruses are the most frequent causes of pneumonia. . $^{[3,4,6-8]}$

The HlNl influenza pandemic of 2009-2010 gave us new insight into the role of the virus in immunocompromised patients. ${ }^{[10-12]}$ The World Health Organization estimated, approximately 16,000 deaths between April 2009 and January 2010. The majority of these deaths corresponded to patients with underlying risk factors, such as metabolic dysfunctions, pregnancy, obesity, and immunosuppression, contributing to worse outcomes. ${ }^{[12,13]}$ In HIV patients, $1.74 \%$ of deaths were caused by $\mathrm{HlNl}$ virus. A recent study in Spain reported that the most frequent (5.4\%) viruses involved in CAP in HIV patients were influenza A and rhinoviruses.

\section{PRINCIPAL RESPIRATORY VIRUSES IN PNEUMONIA}

Details for individual virus discussed below are summarized in Table 2.

\section{Influenza virus}

Influenza viruses are RNA viruses that are classified into types A, B and C. Antigenic drifts of surface proteins are responsible for seasonal epidemics, and is described for both influenza A and B. Severe outbreaks and pandemics due to antigenic shift are less frequent and occur only with influenza A virus. ${ }^{[14]}$ Transmission of influenza virus is by airborne particles or contaminated hands touching nose or mouth. ${ }^{[15]}$
The incubation period is $24-48 \mathrm{~h}$. The viral shedding starts 5 days before the onset of symptoms in healthy adults, but its duration is longer in inmunocompromised patients. ${ }^{[16-18]}$

Influenza is usually self-limiting, but severe complications (e.g., pneumonia) can occur particularly in high-risk individuals including HIV patients, and may lead to significant increases in hospitalization and mortality rates. Nonetheless, there are few data on influenza pneumonia in HIV patients. Recent studies demonstrated that influenza causes increased risk of hospitalization, death, and prolonged illness in HIV patients without ART in comparison to the general population. ${ }^{[19,20]}$

\section{Respiratory syncytial virus}

Respiratory syncytial virus (RSV) is an RNA virus that is classified into two antigenic subgroups A (causes more severe disease) and B. It causes seasonal outbreaks that occur from November to April in the Northern hemisphere and from April to September in the Southern hemisphere, which often last 4-5 months in a community. ${ }^{[21,22]} \mathrm{RSV}$ infection is transmitted through direct contact with viruscontaining secretions, fomites, or large aerosol droplets. Nasal congestion, dyspnea and wheezing are the typical symptoms in RSV pneumonia.

Respiratory syncytial virus has been identified as an important cause of pneumonia in adults. The prevalence of RSV in CAP is 2-5\% throughout the year and $5-14 \%$ during winter. ${ }^{[23,24,25,26]}$ Individuals with higher-risk for 
Cillóniz, et al.: Viral pneumonia in HIV infected patients

\begin{tabular}{|c|c|c|c|c|}
\hline $\begin{array}{l}\text { Respiratory } \\
\text { viruses }\end{array}$ & Mode of transmission & Laboratory diagnosis & Therapy & Vaccine \\
\hline Influenza virus & $\begin{array}{l}\text { Person-to-person by } \\
\text { airborne particles }\end{array}$ & $\begin{array}{l}\text { Culture } \\
\text { Nucleic acid amplification } \\
\text { Antigen detection } \\
\text { Serology }\end{array}$ & $\begin{array}{l}\text { Neuraminidase inhibitors: } \\
\text { Oseltamivir, zanamivir } \\
\text { (influenza A and B) } \\
\text { M2 inhibitors: Amantadine, } \\
\text { rimantadine (influenza A) }\end{array}$ & $\begin{array}{l}\text { Inactivated } \\
\text { influenza vaccine }\end{array}$ \\
\hline $\begin{array}{l}\text { Respiratory } \\
\text { syncitial virus }\end{array}$ & $\begin{array}{l}\text { Direct contact with virus- } \\
\text { containing secretions, } \\
\text { fomites, or large aerosol } \\
\text { droplets }\end{array}$ & $\begin{array}{l}\text { Culture } \\
\text { Nucleic acid amplification } \\
\text { Antigen detection }\end{array}$ & Ribavirin, palivizumab & $\begin{array}{l}\text { Vaccine not } \\
\text { available }\end{array}$ \\
\hline Adenovirus & $\begin{array}{l}\text { Fecal - oral through } \\
\text { fomites and droplets }\end{array}$ & $\begin{array}{l}\text { Culture } \\
\text { Nucleic acid amplification } \\
\text { Antigen detection } \\
\text { Serology }\end{array}$ & Cidofovir, ribavirin & $\begin{array}{l}\text { Vaccine not } \\
\text { available }\end{array}$ \\
\hline Rhinovirus & $\begin{array}{l}\text { Aerosol droplets or } \\
\text { contact with infected } \\
\text { secretions from the } \\
\text { upper airway }\end{array}$ & $\begin{array}{l}\text { Nucleic acid amplification } \\
\text { Antigen detection }\end{array}$ & Pleconaril, interferon therapy & $\begin{array}{l}\text { Vaccine not } \\
\text { available }\end{array}$ \\
\hline Human PIV & $\begin{array}{l}\text { Respiratory droplets, } \\
\text { fomites, or direct contact }\end{array}$ & $\begin{array}{l}\text { Culture } \\
\text { Nucleic acid amplification } \\
\text { Immunoglobulin detection }\end{array}$ & Ribavirin & $\begin{array}{l}\text { Vaccine not } \\
\text { available }\end{array}$ \\
\hline HMPV & $\begin{array}{l}\text { Direct or close contact } \\
\text { with contaminated } \\
\text { secretions including } \\
\text { saliva, droplets or large- } \\
\text { particle aerosols }\end{array}$ & $\begin{array}{l}\text { Nucleic acid amplification } \\
\text { Antigen detection }\end{array}$ & Ribavirin & $\begin{array}{l}\text { Vaccine not } \\
\text { available }\end{array}$ \\
\hline Coronavirus & $\begin{array}{l}\text { Airborn droplets, close } \\
\text { personal contact }\end{array}$ & $\begin{array}{l}\text { Cell culture } \\
\text { Nucleic acid amplification } \\
\text { Serology }\end{array}$ & $\begin{array}{l}\text { No specific treatment is } \\
\text { available }\end{array}$ & $\begin{array}{l}\text { Vaccine not } \\
\text { available }\end{array}$ \\
\hline Cytomegalovirus & $\begin{array}{l}\text { Direct or close contact } \\
\text { with contaminated } \\
\text { secretions }\end{array}$ & $\begin{array}{l}\text { Nucleic acid amplification } \\
\text { Antigen detection } \\
\text { Serology }\end{array}$ & Ganciclovir & $\begin{array}{l}\text { Vaccine not } \\
\text { available }\end{array}$ \\
\hline $\begin{array}{l}\text { Herpes simplex } \\
\text { virus }\end{array}$ & $\begin{array}{l}\text { Close contact with an } \\
\text { infected person who } \\
\text { is shedding virus from } \\
\text { the skin, in saliva, or in } \\
\text { secretions from genitals }\end{array}$ & $\begin{array}{l}\text { Nucleic acid amplification } \\
\text { Serology }\end{array}$ & Aciclovir & $\begin{array}{l}\text { Vaccine not } \\
\text { available }\end{array}$ \\
\hline Human bocavirus & Aerosol and contact & $\begin{array}{l}\text { Nucleic acid amplification } \\
\text { Serology }\end{array}$ & $\begin{array}{l}\text { No specific treatment is } \\
\text { available }\end{array}$ & $\begin{array}{l}\text { Vaccine not } \\
\text { available }\end{array}$ \\
\hline
\end{tabular}

PIV: Parainfluenza virus; HMPV: Human metapneumovirus

developing RSV pneumonia are: Children $<6$ months old, patients with chronic diseases or congenital heart disease, institutionalized elderlies, and immunosuppressed patients. ${ }^{[27]}$ Adults with severe immunodeficiency are at higher-risk for serious RSV infection. ${ }^{[28,29]}$ The clinical presentation in HIV patients is similar to non-HIV patients, but with significantly increased morbidity and mortality while the severity of the infection depends on the magnitude of immunosuppression in each patient. The overall mortality rate in adults varies from $1 \%$ to $5 \%$ in healthy individuals to $41 \%$ in bone marrow transplant recipients. ${ }^{[30]}$

\section{Human rhinovirus}

Human rhinoviruses (HRV) are RNA viruses with more than 100 different strains that are genetically divided into three classes: A, B, and C. ${ }^{[31]}$ They are the most common causative agents of acute upper respiratory tract disease. HRV infections are transmitted by either aerosol droplets or contact with infected secretions from the upper airway.
Advances in diagnosis methods have shown that RV may also cause pneumonia and induce asthma exacerbations. ${ }^{[27]}$ Respiratory symptoms are the result of the destruction of normal airway tissue by the virus and production of proinflammatory immune responses against the virus. ${ }^{[32]}$

In adults, approximately $5-10 \%$ of viral pneumonia are caused by HRV. ${ }^{[33-35]}$ A recent study on CAP among immunocompromised patients found that HRV was responsible for $12 \%$ of the cases, making it the most common virus isolated; the mortality rate was $18 \%$ suggesting that it may have been an underestimated respiratory virus. ${ }^{[4]}$

Human rhinoviruses are one of the most frequent pathogens implicated in mixed respiratory viral infections and was shown in $19.5 \%$ of bronchiolitis by such infection. ${ }^{[36]}$

\section{Human parainfluenza virus}

Human parainfluenza viruses (HPIV) are RNA viruses that are classified into four serotypes (HPIV1-4), all of which 
can cause lower respiratory infection (LRI) in humans such as bronchitis, asthma, and pneumonia especially in infants, young children, elderlies, and immunocompromised individuals. ${ }^{[5,37]}$ Transmission can occur through respiratory droplets, fomites, or direct contact with an infected host. ${ }^{[38]}$

Human parainfluenza viruses type 1 and type 3 are among the major pathogens that cause hospitalization for viral respiratory infection in the world. They are with high prevalence in adults and associated with up to $12 \%$ of acute LRIs. ${ }^{[39,40]}$ HPIV infection is generally limited to the respiratory tract and does not spread systemically unless the infected individual is severely immunocompromised.

Factors contributing to HPIV pathogenesis are young age and lack of prior exposure. Fewer data exist on HPIV pneumonia in patients with HIV. Garbino et al. showed that $5 \%$ of the HIV patients in their study were infected with HPIV, and were all in the context of co-infection with other pathogens. ${ }^{[5]}$

\section{Adenovirus}

Adenoviruses are DNA viruses with approximately 52 serotypes, but only few of them cause diseases in humans with a worldwide distribution throughout the year. Pulmonary infections are associated with serotypes 1, 2, 3, 4, 5, 7, 14, and 21 . Serotype 14 is associated with severe pneumonia in susceptible adults and children including solid-organ transplant recipients, HIV patients, and individuals with other kinds of impaired cell-mediated immunity. ${ }^{[41]}$ Respiratory infection by adenoviruses also accounts for $5-10 \%$ of the pediatric population and $1-7 \%$ of adults. ${ }^{[42]}$ Transmission of adenovirus is fecal — oral through fomites and droplets, and the virus can persists on environmental surfaces for several weeks. Clinical presentation ranges from asymptomatic viremia to respiratory and gastrointestinal disease, hemorrhagic cystitis, and a severe disseminated illness, but is typically characterized by fever, cough, and dyspnea. Pulmonary opacities are often patchy and irregular or reticular at radiological images, but consolidations can also be observed. However, the clinical spectrum of the disease is broad, and dissemination or pneumonia can be fatal in both immunocompetent and immunocompromised patients. ${ }^{[3]}$ Khoo et al. found that the risk of adenovirus infection in patients with acquired immunodeficiency syndrome (AIDS) was $28 \%$ in the $1^{\text {st }}$ year $\left(17 \%\right.$ if CD4+ $4^{+}$-cell count was $>200 / \mathrm{mm}^{3}$ vs. $38 \%$ if the count was $\left.<200 / \mathrm{mm}\right)^{3}$. Adenovirus infection is uncommon in HIV/AIDS patients until their immune systems are impaired. ${ }^{[4]}$

\section{Human metapneumovirus}

Human metapneumovirus (HMPV) is an RNA virus, and HMPV infection has been detected worldwide in the community or hospitalized patients at any age, with most severe cases reported in elderly and immunocompromised patients. HMPV is thought to be transmitted by direct or close contact with contaminated secretions including saliva, droplets, or large-particle aerosols. Symptoms are usually very similar to those caused by RSV, with a range of illness from mild respiratory symptoms to severe bronchiolitis and pneumonia. The incubation period is approximately 5 days, and clinical symptoms are similar to that of other viral infections, with nasal congestion, coughing, wheezing, fever and dyspnea. Chest images show bilateral alveolar opacities in $43 \%$ of cases, and nodular opacities and pleural effusion can also be observed. ${ }^{[45]}$

\section{Coronavirus}

Coronaviruses are RNA viruses that are primarily associated with respiratory infection at any age, worldwide, and cause epidemics every 2-3 years. Approximately $15 \%$ of the common cold in adults are caused by coronaviruses. ${ }^{[46,47]}$ There are five strains associated with respiratory infection in humans: Severe acute respiratory syndrome (SARS) coronavirus produces life-threatening SARS and was identified in 2003 outbreak in China; ${ }^{[48]}$ the human coronaviruses (HCoV)OC43 and HCoV-229E are associated with common cold, and HCoV-NL63 and HCoV-HKUl are associated with LRI infections, which were identified in The Netherlands in 2004 and in Hong Kong in 2005, respectively. ${ }^{[49,50]}$ More recently, Middle East respiratory syndrome-CoV was reported in Saudi Arabia in 2012. The mode of transmission is through aerosol droplets or close personal contact. The infections by coronaviruses mainly occur in winter, with an incubation period of 2-5 days. The most common symptoms are: Myalgia, chills, and dyspnea, with possible progression to respiratory failure whereas fever, is uncommon. The radiological pattern is nonspecific, commonly characterized by diffuse pulmonary ground-glass opacities on chest tomography. In a retrospective study in Hong Kong, coronavirus was presented in $2.1 \%$ of patients hospitalized with acute respiratory illnesses. ${ }^{[51]}$ Several studies demonstrated that coronavirus causes CAP in children and adults. ${ }^{[3,52,53]}$ Garbino et al. found RV in $18.6 \%$ of bronchioalveolar lavage (BAL) samples of HIV patients in the study, and HCoV-OC43 was identified in $27.2 \%$ of such cases. ${ }^{[5]}$ However, few such studies with HIV patients exist.

\section{Cytomegalovirus}

Cytomegalovirus (CMV) is a DNA virus that is highly prevalent in the general population. CMV is a common cause of acute LRI infections particularly in immunocompromised patients and is associated with a wide spectrum of diseases ranging from an asymptomatic disease or a mononucleosislike syndrome to severe disease in immunocompromised patients. ${ }^{[5-56]}$ The principal risk factors for CMV infection include HIV infection and immunnosuppression by transplantation and conditions associated with significant morbidity and mortality. ${ }^{[54-56]} \mathrm{CMV}$ is transmitted by direct or close contact with contaminated secretions, and CMV infection is the most common viral opportunistic infection with a prevalence of $21-44 \%$ in the HIV population before ART therapy. ${ }^{[47]}$ After the resolution of acute infection, 
CMV establishes latent infection. ${ }^{[47]}$ Most HIV patients have latent CMV infection in many tissues including the lungs, and most cases of CMV pneumonia are believed to be caused by CMV reactivation due to severe immunosuppression.

Pneumonia caused by CMV is reported to be similar to that caused by Pneumocystis jirovecii; with fever, cough, hypoxemia, diffuse radiographic opacities, and pleural effusion in $33 \%$ of cases. ${ }^{[47]}$

Salomon et al. demonstrated that $\mathrm{CD}^{+}{ }^{+}$T-cell count $\leq 12 \times 10^{6}$ and extra-pulmonary CMV manifestations were independently associated with CMV pneumonia. ${ }^{[55]}$

\section{Herpes simplex virus}

Herpes simplex virus (HSV) is a DNA virus with two types: HSV-1 and HSV-2, both of which produce lifelong infections and are very common in the general population. The primary infection by this virus is usually asymptomatic, but it establishes lifelong latency. ${ }^{[57]}$ Reactivation of the virus has been associated with asymptomatic virus excretion in saliva, producing ulceration of the mouth mucosa or herpes labialis, and immunocompromissed patients develop a serious disease such as herpetic tracheobronchitis or pneumonia. ${ }^{[58-60]}$ The transmission is due to close contact with an infected person who is shedding virus from the skin, in saliva, or in secretions from genitals. HSV infections, both oral and genital, are frequent in HIV patients with severe immunodeficiency. Herpetic pneumonia is rare in HIV patients; while HSV-l is the usual cause of the cases, pneumonia due to HSV-2 is extremely rare. ${ }^{[61,62]}$ Despite the low frequency of pulmonary infections, sporadic cases of HSV-mediated pneumonia and tracheitis in HIV patients have been reported. ${ }^{[62,63]}$

\section{Human bocavirus}

Bocavirus was first isolated in nasopharyngeal aspirate specimens from children with LRI infections in 2005. ${ }^{[64]}$ It is a DNA virus, which likely is transmitted by respiratory droplets and has been detected worldwide. Several studies suggest that the human bocavirus is mainly a respiratory pathogen. ${ }^{[65-68]}$

In a recent study, $17 \mathrm{RV}$ were tested during the acute phase of CAP in children, and bocavirus was among the most frequently detected virus after RSV and HRV. ${ }^{[69]}$ In a different pediatric population from South Africa, Nunes et al. found presence of bocavirus in $9.5 \%$ of HIV-infected and in $13.3 \%$ of HIV-uninfected children with LRI. ${ }^{[70]}$ In the adult HIV patients, Garbino et al. found only 1 out of the 55 patients $(3.1 \%)$ was positive for bocavirus. ${ }^{[5]}$ Unfortunately, clinical manifestations of bocavirus infection are not well defined, but it has been described to range from mild to severe upper respiratory tract infections.

\section{MICROBIAL DIAGNOSIS}

The key for successful detection of RV is the collection of good quality respiratory tract samples (nasal and oropharyngeal swabs placed in a single viral transport medium). Specimens should be collected preferably within $48 \mathrm{~h}$ from the onset of illness. Current diagnostic methods for RV are: Serology, virus culture, antigen detection, and nucleic acid testing.

\section{Serology}

Serology requires collection of paired blood samples from acute and convalescent phases. Greater than four-fold increase of virus specific IgG in the convalescent phase relative to the acute phase confirm the diagnosis. It is available for many RV including adenovirus, RSV, and seasonal influenza. However, the results do not affect clinical management of patients.

\section{Virus isolation}

Viral culture requires specific technical expertise, is laborintensive and expensive, and takes several days to grow and identify the virus. Viral culture is more sensitive than antigen detection assays and is capable of recovering novel or highly divergent strains that were not detected by other tests. However, some viruses such as rhinovirus, metapneumovirus, coronaviruses, and human bocavirus, grow poorly or not at all in the culture. In addition, this method only detects viable viruses in contrast to the nucleic acid amplification test.

\section{Antigen detection}

Direct and indirect immunofluorescence assays use commercial type-specific monoclonal antibodies to detect viral antigens directly on clinical specimens or in cell culture. These tests mostly have a specificity greater than $80 \%$ and sensitivity of 47-93\% depending on virus and viral load. ${ }^{[71,72]}$ These tests are not available for some viruses (e.g., bocavirus, coronavirus, and rhinovirus), and presents lower sensitivity for detection of viruses in co-infections compared with nucleic acid amplification methods.

Another antigen detection method is rapid antigen detection assays (RIDA). RIDAs give a visual result on an immunochromatographic strip in 10-30 min and are available for influenza virus, adenovirus, and RSV. These assays present a high specificity, but lower sensitivity (10-70\%) compared to nucleic acid amplification and viral culture. ${ }^{[73]}$

\section{NUCLEIC ACID AMPLIFICATION}

Nucleic acid amplification is considered the most sensitive, specific, and versatile test for respiratory virus detection. In addition, it requires a significantly shorter time $(1-5 \mathrm{~h})$ to obtain the result in comparison to other methods. ${ }^{[74]}$ Today, there are many commercial tests and in-house assays. ${ }^{[4]}$ Real-time polymerase chain reaction (PCR) combines the amplification and detection steps, and can quantify the viral 
load in clinical specimens for prognosis and to assess antiviral efficacy. ${ }^{[75]}$ Also, it can simultaneously detect influenza and other RV. ${ }^{[76]}$ Moreover, CMV, HSV, and varicella zoster virus can be detected by PCR in BALs from HIV patients with severe respiratory infection. ${ }^{[77]}$

\section{PREVENTION}

Influenza $\mathrm{A}$ and $\mathrm{B}$ virus infections can be prevented by prophylactic use of neuraminidase-inhibitors. ${ }^{[78]}$ Preventive strategies are recommended in HIV-infected patients due to the possibility for highly morbid viral infections (immunodeficiency) and the high frequency of additional risk factors (e.g., smoking and chronic lung diseases). Current guidelines by prevention and treatment of opportunistic infections in HIV-infected patients recommend annual influenza vaccination to reduce the risk of influenza and postinfluenza bacterial pneumonia in the population. ${ }^{[79]}$ In fact, the prolonged shedding and the increased risk for complications and death in HIV patients make this population an important target for influenza vaccination campaigns.

The protective efficacy of the inactivated influenza vaccine in healthy individuals achieves $70-90 \%{ }^{[80]}$ while that of the HIV patient population is approximately $40 \%$. ${ }^{[81,82]}$ Reasons for decreased antibody responses to the influenza vaccine in HIV patients are not clear; nevertheless, two main predictors for induction of adequate response to influenza vaccine may be higher $\mathrm{CD}^{+}{ }^{+} \mathrm{T}$-cell count $(\geq 200$ cells $/ \mu \mathrm{L})$ and undetectable viral load ( $<50$ copies $/ \mathrm{mL}$ ). Recent studies show that HIV patients reach higher levels of influenza seroprotection if vaccinated with high-dose influenza vaccine. ${ }^{[83,84]}$

For RSV, handwashing and use of gloves are the primary measures to prevent viral transmission from close contact with an infected patients or contaminated surfaces.

For RV infection, the combination of antiviral chemoprophylaxis and control measures such as handwashing would be expected to reduce the risk of LRI particularly in patients with comorbidities.

\section{ANTIVIRAL THERAPY}

For influenza pneumonia, two groups of antiviral drugs are currently available: Matrix protein 2 (M2) inhibitors and neuraminidase inhibitors. M2 inhibitors are only active against influenza A. Unfortunately, resistance against M2 inhibitors can develop as early as 2-3 days after administration of the drug. Therefore, these antivirals should be administered within $48 \mathrm{~h}$ from the onset of symptoms. Oral or inhaled neuraminidase-inhibitors are both effective against influenza A and B viruses. The rate of developing resistance is very low; however, some resistant cases were reported during the $\mathrm{HlNl}$ pandemic. ${ }^{[85]}$ In cases of severe pneumonia, the medication is recommended even after $48 \mathrm{~h}$ from the onset of symptoms.

Ribavirin is a nucleoside analogue that inhibits viral replication; the aerosol form is used for the treatment of RSV in children. Palivizumab is an anti-RSV monoclonal antibody that has been used for prophylaxis and to treat upper and lower respiratory tract RSV infections in severely immunocompromised patients.

Intranasal interferon demonstrated prophylactic efficacy against rhinovirus infection while it is not therapeutically effective in established rhinovirus colds. ${ }^{[86]}$ Pleconaril is the first antiviral to be proven effective in clinical practice to reduce duration and severity of viral respiratory infection symptoms after establishment of the illness. ${ }^{[87]}$

Currently, there is no specific antiviral therapy for HIPV infection. Nonetheless, Chakrabarti et al. reported a good response to ribavirin in HIPV respiratory infections among hematopoietic stem cell transplant recipients. ${ }^{[88]}$

Cidofovir has been used, and several reports demonstrated the efficacy of the combined therapy "cidofovir/ribavirin," especially in patients with unfavorable evolution. ${ }^{[3]}$

There is no specific therapy for HMPV infection. However, Raza et al. reported a successful ribavirin treatment of a lung transplant recipient with severe HMPV pneumonia. ${ }^{[89]}$

To coronavirus infection, no specific treatment is available. However, in severe cases, protease inhibitors (lopinavir and ritonavir) and interferon (alpha and beta) can be administered. ${ }^{\left[{ }^{[0]}\right.}$ There is no evidence of efficacy for ribavirin use.

For the treatment of CMV pneumonia, ganciclovir is recommended in combination with high-dose immunoglobulins while it has not been evaluated in a randomized controlled trial. CMV pneumonia treatment is recommended for patients with HIV if CMV is the sole pathogen and is symptomatic whereas treatment does not seem to result in improved outcome if other pathogens are present. ${ }^{[47]}$

For the treatment of HSV pneumonia, acyclovir has demonstrated beneficial effects in several studies, and the frequency of developing resistance is minimal. ${ }^{[91]}$

Currently, there is no antiviral treatment for bocavirus, and only supportive care is available.

\section{CONCLUSION}

The development of novel diagnostic tests has shown that viral involvements in CAP are more prevalent than was 
described in the past. Community-acquired viral pneumonia is a more serious clinical disease in immunocompromised patients than in the general population. Further investigations are needed to understand the role and clinical impact of the newly identified RV, especially in HIV populations. Unfortunately, vaccines and specific therapies are available only for some RV. Preventive measures are keys to stop the transmissions of these viruses to susceptible hosts and will decrease the morbidity and mortality rates associated with the community-acquired viral pneumonia in the immunocompromised population. Finally, it is worth noting that a wide microbiological analysis is recommended in immunocompromised patients to optimize antimicrobial therapy.

\section{REFERENCES}

1. Mandell LA, Wunderink RG, Anzueto A, Bartlett JG, Campbell GD, Dean NC, et al. Infectious Diseases Society of America/American Thoracic Society consensus guidelines on the management of community-acquired pneumonia in adults. Clin Infect Dis 2007;44 Suppl 2:S27-72.

2. Ruuskanen O, Lahti E, Jennings LC, Murdoch DR. Viral pneumonia. Lancet 2011;377:1264-75.

3. Johnstone J, Majumdar SR, Fox JD, Marrie TJ. Viral infection in adults hospitalized with community-acquired pneumonia: Prevalence, pathogens, and presentation. Chest 2008;134:1141-8.

4. Camps Serra M, Cervera C, Pumarola T, Moreno A, Perelló R, Torres A, et al. Virological diagnosis in community-acquired pneumonia in immunocompromised patients. Eur Respir J 2008;31:618-24.

5. Garbino J, Inoubli S, Mossdorf E, Weber R, Tamm M, Soccal P, et al. Respiratory viruses in HIV-infected patients with suspected respiratory opportunistic infection. AIDS 2008;22:701-5.

6. Perelló R, Moreno A, Camps M, Cervera C, Linares L, Pumarola T, et al. Human immunodeficiency virus-infected patients with community-acquired pneumonia: Implication of respiratory viruses. Enferm Infecc Microbiol Clin 2008;26:85-7.

7. Feng L, Li Z, Zhao S, Nair H, Lai S, Xu W, et al. Viral etiologies of hospitalized acute lower respiratory infection patients in China, 2009-2013. PLoS One 2014; 9: e99419.

8. Cilloniz C, Torres A, Polverino E, Gabarrus A, Amaro R, Moreno E, et al. Community-acquired lung respiratory infections in HIVinfected patients: Microbial aetiology and outcome. Eur Respir J 2014;43:1698-708.

9. Beck JM, Rosen MJ, Peavy HH. Pulmonary complications of HIV infection. Report of the Fourth NHLBI Workshop. Am J Respir Crit Care Med 2001;164:2120-6.

10. Giamarellos-Bourboulis EJ, Raftogiannis M, Antonopoulou A, Baziaka F, Koutoukas P, Savva A, et al. Effect of the novel influenza A (H1N1) virus in the human immune system. PLoS One 2009;4:e8393.

11. Archer BN, Timothy GA, Cohen C, Tempia S, Huma M, Blumberg L, et al. Introduction of 2009 pandemic influenza A virus subtype H1N1 into South Africa: Clinical presentation, epidemiology, and transmissibility of the first 100 cases. J Infect Dis 2012;206 Suppl 1:S148-53.

12. Archer B, Cohen C, Naidoo D, Thomas J, Makunga C, Blumberg L, et al. Interim report on pandemic $\mathrm{H} 1 \mathrm{~N} 1$ influenza virus infections in South Africa, April to October 2009: Epidemiology and factors associated with fatal cases. Euro Surveill 2009;14.

13. Crovari P, Gasparini R. Influenza (AH1N1v) pandemic 2009: An update. J Prev Med Hyg 2009;50:129-30.

14. Schweiger B, Zadow I, Heckler R. Antigenic drift and variability of influenza viruses. Med Microbiol Immunol 2002;191:133-8.

15. Fiore $A E$, Uyeki TM, Broder K, Finelli L, Euler GL, Singleton JA, et al. Prevention and control of influenza with vaccines:
Recommendations of the Advisory Committee on Immunization Practices (ACIP), 2010. MMWR Recomm Rep 2010;59:1-62.

16. Lee N, Chan PK, Hui DS, Rainer TH, Wong E, Choi KW, et al. Viral loads and duration of viral shedding in adult patients hospitalized with influenza. J Infect Dis 2009;200:492-500.

17. Klimov Al, Rocha E, Hayden FG, Shult PA, Roumillat LF, Cox NJ. Prolonged shedding of amantadine-resistant influenzae $A$ viruses by immunodeficient patients: Detection by polymerase chain reactionrestriction analysis. J Infect Dis 1995;172:1352-5.

18. Leekha S, Zitterkopf NL, Espy MJ, Smith TF, Thompson RL, Sampathkumar P. Duration of influenza A virus shedding in hospitalized patients and implications for infection control. Infect Control Hosp Epidemiol 2007;28:1071-6.

19. Sheth AN, Althoff KN, Brooks JT. Influenza susceptibility, severity, and shedding in HIV-infected adults: A review of the literature. Clin Infect Dis 2011;52:219-27.

20. Cohen C, Simonsen L, Sample J, Kang JW, Miller M, Madhi SA, et al. Influenza-related mortality among adults aged 25-54 years with AIDS in South Africa and the United States of America. Clin Infect Dis 2012; 55:996-1003.

21. Mullins JA, Lamonte AC, Bresee JS, Anderson LJ. Substantial variability in community respiratory syncytial virus season timing. Pediatr Infect Dis J 2003;22:857-62.

22. Moore HC, Keil AD, Richmond PC, Lehmann D. Timing of bronchiolitis hospitalisations and respiratory syncytial virus immunoprophylaxis in non-metropolitan Western Australia. Med J Aust 2009;191:574.

23. Dowell SF, Anderson LJ, Gary HE Jr, Erdman DD, Plouffe JF, File TM Jr, et al. Respiratory syncytial virus is an important cause of community-acquired lower respiratory infection among hospitalized adults. J Infect Dis 1996;174:456-62.

24. Zambon MC, Stockton JD, Clewley JP, Fleming DM. Contribution of influenza and respiratory syncytial virus to community cases of influenza-like illness: An observational study. Lancet 2001;358:1410-6.

25. Griffin MR, Coffey CS, Neuzil KM, Mitchel EF Jr, Wright PF, Edwards KM. Winter viruses: Influenza- and respiratory syncytial virus-related morbidity in chronic lung disease. Arch Intern Med 2002; 162:1229-36.

26. Ellis SE, Coffey CS, Mitchel EF Jr, Dittus RS, Griffin MR. Influenzaand respiratory syncytial virus-associated morbidity and mortality in the nursing home population. J Am Geriatr Soc 2003;51:761-7.

27. Ison MG, Hayden FG. Viral infections in immunocompromised patients: What's new with respiratory viruses? Curr Opin Infect Dis 2002; $15: 355-67$

28. Walsh EE, Falsey AR. Respiratory syncytial virus infection in adult populations. Infect Disord Drug Targets 2012;12:98-102.

29. Ebbert JO, Limper AH. Respiratory syncytial virus pneumonitis in immunocompromised adults: Clinical features and outcome. Respiration 2005;72:263-9.

30. Falsey AR, Hennessey PA, Formica MA, Cox C, Walsh EE. Respiratory syncytial virus infection in elderly and high-risk adults. N Engl J Med 2005;352:1749-59.

31. Palmenberg AC, Spiro D, Kuzmickas R, Wang S, Djikeng A, Rathe JA, et al. Sequencing and analyses of all known human rhinovirus genomes reveal structure and evolution. Science 2009;324:55-9.

32. Gern JE. The ABCs of rhinoviruses, wheezing, and asthma. J Virol 2010;84:7418-26.

33. Lieberman D, Shimoni A, Shemer-Avni Y, Keren-Naos A, Shtainberg $R$, Lieberman D. Respiratory viruses in adults with communityacquired pneumonia. Chest 2010;138:811-6.

34. Cillóniz C, Ewig S, Polverino E, Marcos MA, Prina E, Sellares J, et al. Community-acquired pneumonia in outpatients: Aetiology and outcomes. Eur Respir J 2012;40:931-8.

35. Sangil A, Calbo E, Robles A, Benet S, Viladot ME, Pascual V, et al. Aetiology of community-acquired pneumonia among adults in an H1N1 pandemic year: The role of respiratory viruses. Eur J Clin Microbiol Infect Dis 2012;31:2765-72. 
36. Papadopoulos NG, Moustaki M, Tsolia M, Bossios A, Astra E, Prezerakou A, et al. Association of rhinovirus infection with increased disease severity in acute bronchiolitis. Am J Respir Crit Care Med 2002; 165:1285-9.

37. Reed G, Jewett PH, Thompson J, Tollefson S, Wright PF. Epidemiology and clinical impact of parainfluenza virus infections in otherwise healthy infants and young children $<5$ years old. $J$ Infect Dis 1997; 175:807-13.

38. Lewis VA, Champlin R, Englund J, Couch R, Goodrich JM, Rolston K, et al. Respiratory disease due to parainfluenza virus in adult bone marrow transplant recipients. Clin Infect Dis 1996;23:1033-7.

39. Azevedo AM, Durigon EL, Okasima V, Queiroz DA, de MoraesVasconcelos D, Duarte AJ, et al. Detection of influenza, parainfluenza, adenovirus and respiratory syncytial virus during asthma attacks in children older than 2 years old. Allergol Immunopathol (Madr) 2003;31:311-7.

40. Matsuse $\mathrm{H}$, Kondo $\mathrm{Y}$, Saeki S, Nakata H, Fukushima C, Mizuta $\mathrm{Y}$, et al. Naturally occurring parainfluenza virus 3 infection in adults induces mild exacerbation of asthma associated with increased sputum concentrations of cysteinyl leukotrienes. Int Arch Allergy Immunol 2005; 138:267-72.

41. Louie JK, Kajon AE, Holodniy M, Guardia-LaBar L, Lee B, Petru AM, et al. Severe pneumonia due to adenovirus serotype 14: A new respiratory threat? Clin Infect Dis 2008;46:421-5.

42. Lee J, Choi EH, Lee HJ. Comprehensive serotyping and epidemiology of human adenovirus isolated from the respiratory tract of Korean children over 17 consecutive years (1991-2007). J Med Virol 2010;82:624-31.

43. Echavarría M. Adenoviruses in immunocompromised hosts. Clin Microbiol Rev 2008;21:704-15.

44. Khoo SH, Bailey AS, de Jong JC, Mandal BK. Adenovirus infections in human immunodeficiency virus-positive patients: Clinical features and molecular epidemiology. J Infect Dis 1995;172:629-37.

45. Haas LE, Thijsen SF, van Elden L, Heemstra KA. Human metapneumovirus in adults. Viruses 2013;5:87-110.

46. McIntosh K, Kapikian AZ, Turner HC, Hartley JW, Parrott RH, Chanock RM. Seroepidemiologic studies of coronavirus infection in adults and children. Am J Epidemiol 1970;91:585-92.

47. Vigil KJ, Adachi JA, Chemaly RF. Viral pneumonias in immunocompromised adult hosts. J Intensive Care Med 2010;25:307-26

48. Peiris JS, Yuen KY, Osterhaus AD, Stöhr K. The severe acute respiratory syndrome. N Engl J Med 2003;349:2431-41.

49. Fouchier RA, Hartwig NG, Bestebroer TM, Niemeyer B, de Jong JC, Simon $\mathrm{JH}$, et al. A previously undescribed coronavirus associated with respiratory disease in humans. Proc Natl Acad Sci U S A 2004; 101:6212-6.

50. van der Hoek L, Pyrc K, Jebbink MF, Vermeulen-Oost W, Berkhout RJ, Wolthers KC, et al. Identification of a new human coronavirus. Nat Med 2004; 10:368-73.

51. Peiris JS, Lai ST, Poon LL, Guan Y, Yam LY, Lim W, et al. Coronavirus as a possible cause of severe acute respiratory syndrome. Lancet 2003;361:1319-25.

52. Jennings LC, Anderson TP, Beynon KA, Chua A, Laing RT, Werno AM, et al. Incidence and characteristics of viral communityacquired pneumonia in adults. Thorax 2008;63:42-8.

53. Angeles Marcos M, Camps M, Pumarola T, Antonio Martinez J, Martinez $\mathrm{E}$, Mensa J, et al. The role of viruses in the aetiology of community-acquired pneumonia in adults. Antivir Ther 2006;11:351-9.

54. Zamora MR. DNA viruses (CMV, EBV, and the herpesviruses). Semin Respir Crit Care Med 2011;32:454-70.

55. Salomon N, Gomez T, Perlman DC, Laya L, Eber C, Mildvan D. Clinical features and outcomes of HIV-related cytomegalovirus pneumonia. AIDS 1997;11:319-24.

56. Waxman AB, Goldie SJ, Brett-Smith H, Matthay RA. Cytomegalovirus as a primary pulmonary pathogen in AIDS. Chest 1997;111:128-34.

57. Simoons-Smit AM, Kraan EM, Beishuizen A, Strack van Schijndel RJ, Vandenbroucke-Grauls CM. Herpes simplex virus type 1 and respiratory disease in critically-ill patients: Real pathogen or innocent bystander? Clin Microbiol Infect 2006;12:1050-9.

58. Bruynseels P, Jorens PG, Demey HE, Goossens H, Pattyn SR, Elseviers MM, et al. Herpes simplex virus in the respiratory tract of critical care patients: A prospective study. Lancet 2003;362:1536-41.

59. Prellner T, Flamholc L, Haidl S, Lindholm K, Widell A. Herpes simplex virus - the most frequently isolated pathogen in the lungs of patients with severe respiratory distress. Scand J Infect Dis 1992;24:283-92.

60. Engelmann I, Gottlieb J, Meier A, Sohr D, Ruhparwar A, Henke-Gendo C, et al. Clinical relevance of and risk factors for HSVrelated tracheobronchitis or pneumonia: Results of an outbreak investigation. Crit Care 2007;11:R119.

61. Furrer $\mathrm{H}$, Meister $F$, Malinverni R. Herpes simplex type 2 pneumonitis in an AIDS patient. Schweiz Med Wochenschr 1989;119:1275-8.

62. Calore EE. Herpes simplex type 2 pneumonia. Braz J Infect Dis 2002;6:305-8.

63. Baras L, Farber CM, Van Vooren JP, Parent D. Herpes simplex virus tracheitis in a patient with the acquired immunodeficiency syndrome. Eur Respir J 1994;7:2091-3.

64. Allander T, Tammi MT, Eriksson M, Bjerkner A, Tiveljung-Lindell A, Andersson B. Cloning of a human parvovirus by molecular screening of respiratory tract samples. Proc Natl Acad Sci U S A 2005;102:12891-6.

65. Fry AM, Lu X, Chittaganpitch M, Peret T, Fischer J, Dowell SF, et al. Human bocavirus: A novel parvovirus epidemiologically associated with pneumonia requiring hospitalization in Thailand. J Infect Dis 2007; 195: 1038-45.

66. Tozer SJ, Lambert SB, Whiley DM, Bialasiewicz S, Lyon MJ, Nissen MD, et al. Detection of human bocavirus in respiratory, fecal, and blood samples by real-time PCR. J Med Virol 2009;81:488-93.

67. Christensen A, Nordbø SA, Krokstad S, Rognlien AG, Døllner H. Human bocavirus commonly involved in multiple viral airway infections. J Clin Virol 2008;41:34-7.

68. Christensen A, Nordbø SA, Krokstad S, Rognlien AG, Døllner H. Human bocavirus in children: Mono-detection, high viral load and viraemia are associated with respiratory tract infection. J Clin Virol 2010;49:158-62.

69. Esposito S, Daleno C, Prunotto G, Scala A, Tagliabue C, Borzani I, et al. Impact of viral infections in children with community-acquired pneumonia: Results of a study of 17 respiratory viruses. Influenza Other Respir Viruses 2013;7:18-26.

70. Nunes MC, Kuschner Z, Rabede Z, Madimabe R, Van Niekerk N, Moloi J, et al. Clinical epidemiology of bocavirus, rhinovirus, two polyomaviruses and four coronaviruses in HIV-infected and HIVuninfected South African children. PLoS One 2014;9:e86448.

71. Rovida F, Percivalle E, Zavattoni M, Torsellini M, Sarasini A, Campanini G, et al. Monoclonal antibodies versus reverse transcription-PCR for detection of respiratory viruses in a patient population with respiratory tract infections admitted to hospital. J Med Virol 2005;75:336-47.

72. Perosa AH, Watanabe AS, Guatura SB, Silva ER, Granato C, Bellei N. Comparison of the direct fluorescence assay and realtime polymerase chain reaction for the detection of influenza virus $A$ and $B$ in immunocompromised patients. Clinics (Sao Paulo) 2013;68:1206-9.

73. Chartrand C, Leeflang MM, Minion J, Brewer T, Pai M. Accuracy of rapid influenza diagnostic tests: A meta-analysis. Ann Intern Med 2012;156:500-11.

74. Johansson N, Kalin M, Tiveljung-Lindell A, Giske CG, Hedlund J. Etiology of community-acquired pneumonia: Increased microbiological yield with new diagnostic methods. Clin Infect Dis 2010;50:202-9.

75. To KK, Chan KH, Li IW, Tsang TY, Tse H, Chan JF, et al. Viral load in patients infected with pandemic H1N1 2009 influenza A virus. J Med Virol 2010;82:1-7.

76. Pillet S, Lardeux M, Dina J, Grattard F, Verhoeven P, Le Goff J, et al. Comparative evaluation of six commercialized multiplex PCR kits for the diagnosis of respiratory infections. PLoS One 2013;8:e72174. 
77. Jouneau S, Poineuf JS, Minjolle S, Tattevin P, Uhel F, Kerjouan M, et al. Which patients should be tested for viruses on bronchoalveolar lavage fluid? Eur J Clin Microbiol Infect Dis 2013;32:671-7.

78. Harper SA, Bradley JS, Englund JA, File TM, Gravenstein S, Hayden FG, et al. Seasonal influenza in adults and children - diagnosis, treatment, chemoprophylaxis, and institutional outbreak management: Clinical practice guidelines of the Infectious Diseases Society of America. Clin Infect Dis 2009;48:1003-32.

79. Kaplan JE, Benson C, Holmes KK, Brooks JT, Pau A, Masur H, et al. Guidelines for prevention and treatment of opportunistic infections in HIV-infected adults and adolescents: Recommendations from CDC, the National Institutes of Health, and the HIV Medicine Association of the Infectious Diseases Society of America. MMWR Recomm Rep 2009;58:1-207.

80. Jefferson T, Di Pietrantonj C, Rivetti A, Bawazeer GA, Al-Ansary LA, Ferroni E. Vaccines for preventing influenza in healthy adults. Cochrane Database Syst Rev 2014;3:CD001269.

81. Tebas P, Frank I, Lewis M, Quinn J, Zifchak L, Thomas A, et al. Poor immunogenicity of the H1N1 2009 vaccine in well controlled HIV-infected individuals. AIDS 2010;24:2187-92.

82. Kelly D, Burt K, Missaghi B, Barrett L, Keynan Y, Fowke K, et al. Responses to pandemic ASO3-adjuvanted A/California/07/09 $\mathrm{H} 1 \mathrm{~N} 1$ influenza vaccine in human immunodeficiency virus-infected individuals. BMC Immunol 2012;13:49.

83. McKittrick N, Frank I, Jacobson JM, White CJ, Kim D, Kappes R, et al. Improved immunogenicity with high-dose seasonal influenza vaccine in HIV-infected persons: A single-center, parallel, randomized trial. Ann Intern Med 2013; 158:19-26.

84. El Sahly HM, Davis C, Kotloff K, Meier J, Winokur PL, Wald A, et al. Higher antigen content improves the immune response to 2009 H1N1 influenza vaccine in HIV-infected adults: A randomized clinical trial. J Infect Dis 2012;205:703-12.

85. Speers DJ, Williams SH, Pinder M, Moody HR, Hurt AC, Smith DW. Oseltamivir-resistant pandemic (H1N1) 2009 influenza in a severely ill patient: The first Australian case. Med J Aust 2010;192:166-8.

86. Hayden FG. Rhinovirus and the lower respiratory tract. Rev Med Virol 2004;14:17-31.

87. Hayden FG, Herrington DT, Coats TL, Kim K, Cooper EC, Villano SA, et al. Efficacy and safety of oral pleconaril for treatment of colds due to picornaviruses in adults: Results of 2 double-blind, randomized, placebo-controlled trials. Clin Infect Dis 2003;36:1523-32.

88. Chakrabarti S, Collingham KE, Holder K, Oyaide S, Pillay D, Milligan DW. Parainfluenza virus type 3 infections in hematopoetic stem cell transplant recipients: Response to ribavirin therapy. Clin Infect Dis 2000;31:1516-8.

89. Raza K, Ismailjee SB, Crespo M, Studer SM, Sanghavi S, Paterson DL, et al. Successful outcome of human metapneumovirus (hMPV) pneumonia in a lung transplant recipient treated with intravenous ribavirin. J Heart Lung Transplant 2007;26:862-4.

90. Haagmans $\mathrm{BL}$, Osterhaus $\mathrm{AD}$. Coronaviruses and their therapy. Antiviral Res 2006;71:397-403.

91. Thoden J, Potthoff A, Bogner JR, Brockmeyer NH, Esser S, Grabmeier-Pfistershammer $\mathrm{K}$, et al. Therapy and prophylaxis of opportunistic infections in HIV-infected patients: A guideline by the German and Austrian AIDS societies (DAIG/ÖAG) (AWMF 055/066). Infection 2013;41 Suppl 2:S91-115.

How to cite this article: Cillóniz C, Yamamoto S, Rangel E, Torres A. Community-acquired viral pneumonia in human immunodeficiency virus infected patients. Community Acquir Infect 2014;1:44-52.

Source of Support: Nil, Conflict of Interest: None declared 